\title{
PERENCANAAN STRUKTUR BENDUNGAN BANDUNGHARJO DESA BANDUNGHARJO - KECAMATAN TOROH KABUPATEN GROBOGAN
}

\author{
Wibowo1) Edy Purwanto2) Martini Indah Krisyanti3) \\ 1) Pengajar Prodi Teknik Sipil Fakultas Teknik UNS \\ 2) Pengajar Prodi Teknik Sipil Fakults Teknik UNS \\ 3) Mahasiswa Prodi Teknik Sipil Fakultas Teknik UNS
}

\begin{abstract}
Grobogan Regency is a producer of rice and corn. To support and increase food production, the availability of sufficient irrigation water is needed. Especially in Bandungharjo Village, Toroh District is a region with relatively little water availability. As a fulfillment of irrigation water and raw water needs in the area, water management is needed. One of the technical solutions is the construction of a Dam. Bandungharjo Village is located at $110^{\circ} 15^{\prime} B T-111^{\circ} 25^{\prime} B T$ and $7^{\circ} \mathrm{LS}-7^{\circ}$ 30'LS has sufficient contour conditions and is drained by Sungai Glugu which has a drainage area of 14,4365 km2. In planning the Bandungharjo Dam, analysis of rainfall data was carried out first so that Flood Discharge for the 50-year return period was obtained, $414.263 \mathrm{m3} /$ second and Retrieval Discharge was $0.375 \mathrm{m3} / \mathrm{sec}$ and with Dam Total Capacity of 17735790,9254 m3. Bandungharjo Dam is planned with the specifications of the Zonal Urugan Dam with Upright Water Resistant Core with Dam height of $38 \mathrm{~m}$. The constituent material consists of clay (core), urugan soil, sand, rip-rap. In control of the stability of the dam control is carried out on avalanches by using the Round Slope Method in the condition that the dam is completed, when the flood water level and when a rapid drawdown is obtained FSK = 2.151> 1.2 (in flood water conditions). And control of seepage (filtration) obtained $Q f=98.152 \mathrm{~m} 3 /$ day $=0.00114 \mathrm{m3} /$ second. While the carrying capacity of the soil using the Terzaghi method in the local shear failure condition was obtained SF = 3,425> 3 . Key Words : Bandungharjo Dam, Dam Specifications, Controls

Dam Stability

Abstrak

Kabupaten Grobogan adalah penghasil padi dan jagung. Untuk menunjang dan meningkatkan produksi pangan tersebut diperlukan ketersediaan air irigasi yang cukup. Khususnya di Desa Bandungharjo, Kecamatan Toroh merupakan daerah dengan ketersediaan air yang relatif sedikit. Sebagai pemenuhan kebutuhan air irigasi dan air baku di daerah tersebut, diperlukan adanya manajemen air. Salah satu penyelesaian teknisnya adalah pembangunan Bendungan. Desa Bandungharjo terletak pada $110^{\circ} 15^{\prime} \mathrm{BT}-111^{\circ} 25^{\prime} \mathrm{BT}$ dan $7^{\circ} \mathrm{LS}-7^{\circ} 30^{\prime} \mathrm{LS}$ mempunyai kondisi kontur (cekungan) yang cukup dan dialiri oleh Sungai Glugu yang memiliki luas daerah pengalirannya sebesar $14,4365 \mathrm{~km}^{2}$.

Dalam perencanaan Bendungan Bandungharjo dilakukan analisis data hujan terlebih dahulu sehingga didapatkan Debit Banjir untuk periode ulang 50 tahun adalah 414,263 $\mathrm{m}^{3} / \mathrm{detik}_{\text {dan }}$ Debit Pengambilan sebesar $0,375 \mathrm{~m}^{3} /$ detik serta dengan Kapasitas Total Bendungan sebesar $17735790,9254 \mathrm{~m}^{3}$. Bendungan Bandungharjo direncanakan dengan spesifikasi Bendungan Urugan Zonal dengan Inti Kedap Air Tegak dengan tinggi Bendungan $38 \mathrm{~m}$. Material penyusunnya terdiri dari lempung (inti), tanah urugan, pasir, rip-rap.

Pada kontrol kestabilan bendungan ini dilakukan kontrol terhadap longsoran dengan menggunakan Metode Irisan Bidang Luncur Bundar pada kondisi bendungan selesai dibangun, saat muka air banjir dan saat penurunan mendadak (rapid drawdown) didapatkan $\mathrm{FS}_{\text {kritis }}=2,151>1,2$ (pada kondisi muka air banjir). Serta kontrol terhadap rembesan (filtrasi) didapatkan Qf $=98,152$ $\mathrm{m}^{3} /$ hari $=0,00114 \mathrm{~m}^{3} /$ detik. Sedangkan Daya Dukung Tanahnya menggunakan metode Terzaghi pada kondisi keruntuhan geser lokal didapatkan $\mathrm{SF}=3,425>3$.
\end{abstract}

Kata kunci: : Bendungan Bandungharjo, Spesifikasi Bendungan, Kontrol 


\section{PENDAHULUAN}

Air merupakan karunia Allah SWT yang tidak ternilai dan terbarukan. Tidak adanya air akan berdampak tiadanya kehidupan di alam ini. Air merupakan kebutuhan pokok manusia dan makhluk hidup lainnya. Ketersediaan air pada musim penghujan melimpah, bahkan seringkali terjadi bencana banjir karena tidak adanya pengelolaan yang baik, sedangkan pada saat musim kemarau ketersediaan air semakin kecil bahkan terjadi kekeringan di sebagian daerah. Pemanfaatan sumber daya alam yang tidak mengindahkan konservasi tanah dan air akan semakin mereduksi ketersediaan air (terutama pada musim kemarau). Tindakan-tindakan manusia yang mereduksi ketersediaan air sebagai berikut: pemanfaatan hutan untuk industri tanpa adanya reboisasi, pembukaan lahan pertanian baru, penambangan sumber daya alam tanpa konservasi.

Pola dan strategi pemanfaatan air harus mempertimbangkan kebutuhan dan ketersediaan air secara ruang dan waktu serta mempertimbangkan konservasi air. Pola manajemen air yang mempertimbangkan ketersediaan dan kebutuhan air secara ruang dan waktu, akan didapatkan manfaat air secara optimal tanpa mengganggu keseimbangan lingkungan hidup. Pola dan strategi air secara optimal tersurat dalam Pasal 3 Undang-Undang No.7/2004 tentang Sumber Daya Air, bahwa sumber daya air dikelola secara menyeluruh, terpadu dan berwawasan lingkungan hidup dengan tujuan mewujudkan kemanfaatan sumber daya air yang berkelanjutan untuk sebesar-besarnya kemakmuran rakyat. Pasal 27 ayat 1 pada penjelasan yang dimaksud dengan zona pemanfaatan sumber air adalah ruang pada sumber air (waduk, danau, rawa atau sungai) yang dialokasikan baik sebagai fungsi lindung maupun fungsi budi daya.

Wilayah Kabupaten Grobogan sebagai penghasil padi dan jagung masih memerlukan ketersediaan air irigasi untuk menunjang dan meningkatkan produksi pangan tersebut. Desa Bandungharjo Kecamatan Toroh merupakan salah satu daerah dengan ketersediaan sumber air yang relatif sedikit, sehingga dibutuhkan sistem manajemen air yang akan menyimpan kelebihan air pada musim penghujan dan akan memanfaatkan air pada musim kemarau. Salah satu penyelesaian teknis di dalam menyimpan air pada kondisi berlebih dan mengeluarkan air pada saat kekurangan air adalah dengan pembangunan bendungan, yaitu dengan mempertimbangkan kondisi kontur (cekungan) di daerah Bandungharjo dan kondisi geologi secara makro. Dengan adanya waduk di daerah tersebut diharapkan dapat mencetak sawah baru dari tegalan menjadi sawah irigasi teknis. Areal sawah tersebut meliputi Desa Bandungharjo dan desa-desa disekitarnya yang secara geografis dapat memanfaatkan air dari Waduk Bandungharjo tersebut.

\section{Landasan Teori}

A. Analisis Data HujanUntuk menganalisis data hujan, maka diperlukan alat untuk mengukurnya yaitu penakar hujan. Ketetapan dalam memilih lokasi dan peralatan baik curah hujan maupun debit merupakan faktor yang menentukan kualitas data yang diperoleh. Data curah hujan yang dipakai untuk perhitungan debit banjir adalah hujan yang terjadi pada Daerah Aliran Sungai (DAS) pada waktu yang sama (Sosrodarsono, 1993).

B. Analisis Penentuan Kapasitas Waduk

Dalam penentuan kapasitas waduk senantiasa dipertimbangkan hal-hal sebagai berikut :

1. Besarnya kebutuhan air yang dilayani.

2. Besarnya aliran (ketersediaan air yang ada).

3. Kondisi tampungan yang memungkinkan (pengaruh topografi geologi).

4. Biaya ekonomis dalam pelaksanaan proyek.

5. Besarnya banjir yang akan diredam (terkait dalam perencanaan Spillway, kolam olak, tinggi bendungan) jika waduk juga berfungsi sebagai pengendalian banjir.

Pada perencanaan kapasitas waduk ini menggunakan metode Algoritma Puncak Urutan. Algoritma Puncak Urutan adalah dengan menggambarkan hubungan antara Aliran Netto (Aliran - Kebutuhan air) dengan waktu. Persamaan yang digunakan sebagai berikut :

$\mathrm{St}=\mathrm{St}-1+\mathrm{EVt}+\mathrm{P}+$ Kebutuhan Air - Inflow

Dimana

St $\quad=$ tampungan bendungan pada akhir bulan ke-t

St-1 = tampungan bendungan pada akhir bulan sebelumnya

$\mathrm{EVt} \quad=$ penguapan yang terjadi pada permukaan waduk

$\mathrm{P} \quad=$ perkolasi 
Keb Air = kebutuhan air yang diperlukan (outflow)

Inflow $\quad=$ pemasukan air dari debit keandalan

Data hujan yang dipakai adalah 15 tahun sejak 1998-2012 (data terlampir), untuk daerah peta Sub DAS Sungai Glugu dipilih 4 stasiun hujan yaitu Stasiun A di Desa Geyer, Stasiun B di Desa Asemrudung, Stasiun C di Desa Sanggeh, Stasiun D di Desa Semen. Dalam penentuan analisis data hujan

\section{Penulusan Banjir pada Bendungan}

Penelusuran banjir diartikan sebagai suatu prosedur untuk menentukan (memperkirakan) waktu dan besaran banjir di suatu titik di sungai berdasar data yang telah diketahui di sungai sebelah hulu (Lawler, 1964).

Penelusuran banjir dilakukan karena sungai merupakan bagian yang sangat penting bagi kehidupan manusia. Oleh sebab itu, keadaan ekstrim alirannya baik kekeringan maupun banjir tidak dikehendaki. Terutama sekali untuk kasus banjir, perlindungan terhadap aspek kehidupan di sepanjang sungai perlu diperhatikan. Oleh sebab itu, peranan penelusuran banjir (flood routing) yang merupakan bagian analisis hidrologi menjadi panjang (Sri harto, 1993).

Routing hidrograf banjir melewati waduk dengan keluaran air dari waduk berupa buangan air melalui bangunan pelimpah adalah salah satu aspek hidrologi dan hidrolika yang penting.

Rumus dasar yang digunakan adalah rumus kontinuitas yang mengatakan bahwa perubahan volume air tampungan pada waduk sama dengan selisih antara inflow (masukan) dan outflow (keluaran)

Formulasi untuk hitungan sering ditulis dengan notasi (Sudjarwadi, 1987):

$\Delta \mathrm{I}-\Delta \mathrm{O}=\Delta \mathrm{S}$

Dimana :

$\Delta \mathrm{I} \quad=$ inflow rerata pada periode $\mathrm{Dt}$

$\Delta \mathrm{O} \quad=$ outflow rerata pada periode $\mathrm{Dt}$

$\Delta \mathrm{S} \quad=$ perubahan tampungan selama periode Dt yang sedang ditinjau

Dt = periode (waktu) sebagai interval untuk diskritisasi hitungan

Pada penelusuran banjir pada perencanaan bendungan ini menggunakan iterasi cara Newton Rapshon dengan persamaan sebagai berikut

Persoalan routing hidrograf banjir melewati bangunan pelimpah dapat dibawa pada satu bentuk persamaan yang pencarian tinggi luapan diatas mercu pelimpah dapat dicari dengan iterasi Newton Rapshon. Karena rumus debit keluaran lewat bangunan pelimpah pada suatu saat dapat dihitung berdasar rumus yang diketahui tersebut dengan tinggi luapan di atas mercu sebagai variabel. Persamaan pelimpah (Spillway) ambang lebar dengan elevasi dan volume sebagai berikut :

$\mathrm{Q}=C_{d} \cdot B \cdot H^{3 / 2}$

\section{Dimana :}

$\mathrm{Q}=$ = debit yang melewati spillway (m3/detik)

$\mathrm{Cd} \quad=$ koefisien debit limpasan

B = lebar efektif limpasan (m) 
$\mathrm{H} \quad=$ perbedaan muka air antara hulu dan hilir $(\mathrm{m}$

\section{Metode Penelitian}

Data yang digunakan dalam penelitian tugas akhir ini adalah data sekunder dan data primer. Adapun data sekunder atau data yang diambil langsung di lapangan didapatkan dengan cara observasi melalui survey langsung ke lapangan. Data sekunder atau data yang didapat tidak langsung diperoleh dari instansi terkait yaitu Balai Besar Wilayah Sungai Pemali-Juana di Semarang serta Dinas Pekerjaan Umum Pengairan Kabupaten Grobogan.

Data tersebut kemudian diolah menjadi data siap pakai, data yang sudah diolah kemudian menjadi data masukan dalam analisis selanjutnya. Data-data tersebut adalah sebagai berikut:

1. Data Topografi

Berupa Peta BAKOSURTANAL 1999 yang didapatkan dari Balai Besar Wilayah Sungai Pemali-Juana di Semarang.

2. Data Geologi

Berupa informasi susunan lapisan tanah, sifat dan jenis batuan pada sekitar Sub DAS Kali glugu yang didapatkan dari Balai Besar Wilayah Sungai Pemali-Juana di Semarang.

3. Data Hidrologi

Berupa data curah hujan yang telah diukur secara langsung oleh staf/karyawan Dinas Pekerjaan Umum Pengairan Kabupaten Grobogan. Diambil data curah hujan selama 15 tahun (Tahun 1998 - 2012)

Data hujan harian diambil dari empat stasiun hujan yang berada disekitar Sub DAS Kali Glugu yang antara lain :

a. Stasiun Pengamatan Hujan Desa Geyer

b. Stasiun Pengamatan Hujan Desa Asemrudung

c. Stasiun Pengamatan Hujan Desa Sanggeh

d. Stasiun Pengamatan Hujan Desa Semen

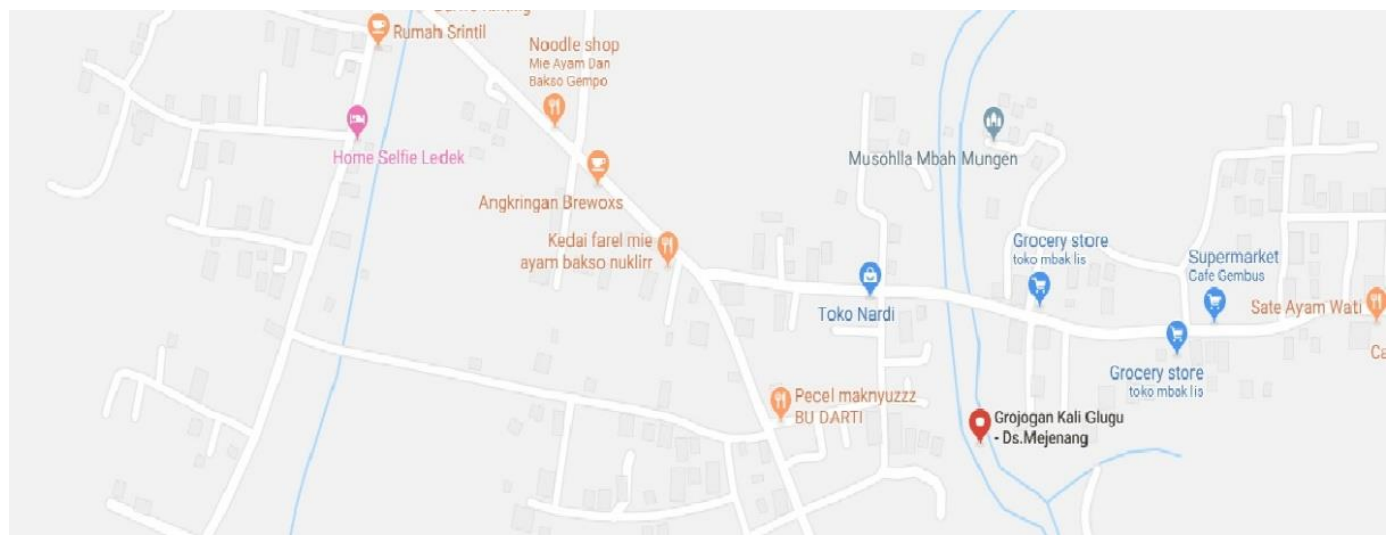

Gambar 1. Denah Lokasi Kali Glugu

4. Data Tanah

Berupa uji tanah di sekitar Sub DAS seperti uji permeabilitas dan pengujian test pit untuk mencari kepadatan, kohesi dan kuat geser tanah. yang didapatkan dari Balai Besar Wilayah Sungai Pemali-Juana di Semarang.

\section{B. Pengolahan Data}

Setelah semua data terkumpul maka perlu dilakukan pengolahan data untuk melakukan perhitungan selanjutnya. Adapun pengolahan data yang ada adalah sebagai berikut :

1. a. Analisis Data Hujan

Analisis data hujan ini meliputi :

1) Pengisian data hujan

2) Uji Konsistensi

3) Curah hujan areal

4) Analisis frekuensi 
5) Debit banjir rencana

b. Data Kebutuhan dan Ketersediaan Air

2. Analisis penentuan kapasitas waduk pada bendungan

3. Analisis penelusuran banjir pada bendungan

4. Desain struktur bendungan

5. Analisis kestabilan terhadap longsoran baik saat muka air banjir maupun saat mengalami penurunan air mendadak (Rapid Drawdown).

6. Analisis kestabilan terhadap rembesan atau filtrasi.

Tahapan pelaksanaan Tugas Akhir "Perencanaan Bendungan Bandungharjo Kecamatan Toroh Kabupaten Grobogan” dapat dilihat pada Gambar IV.1.

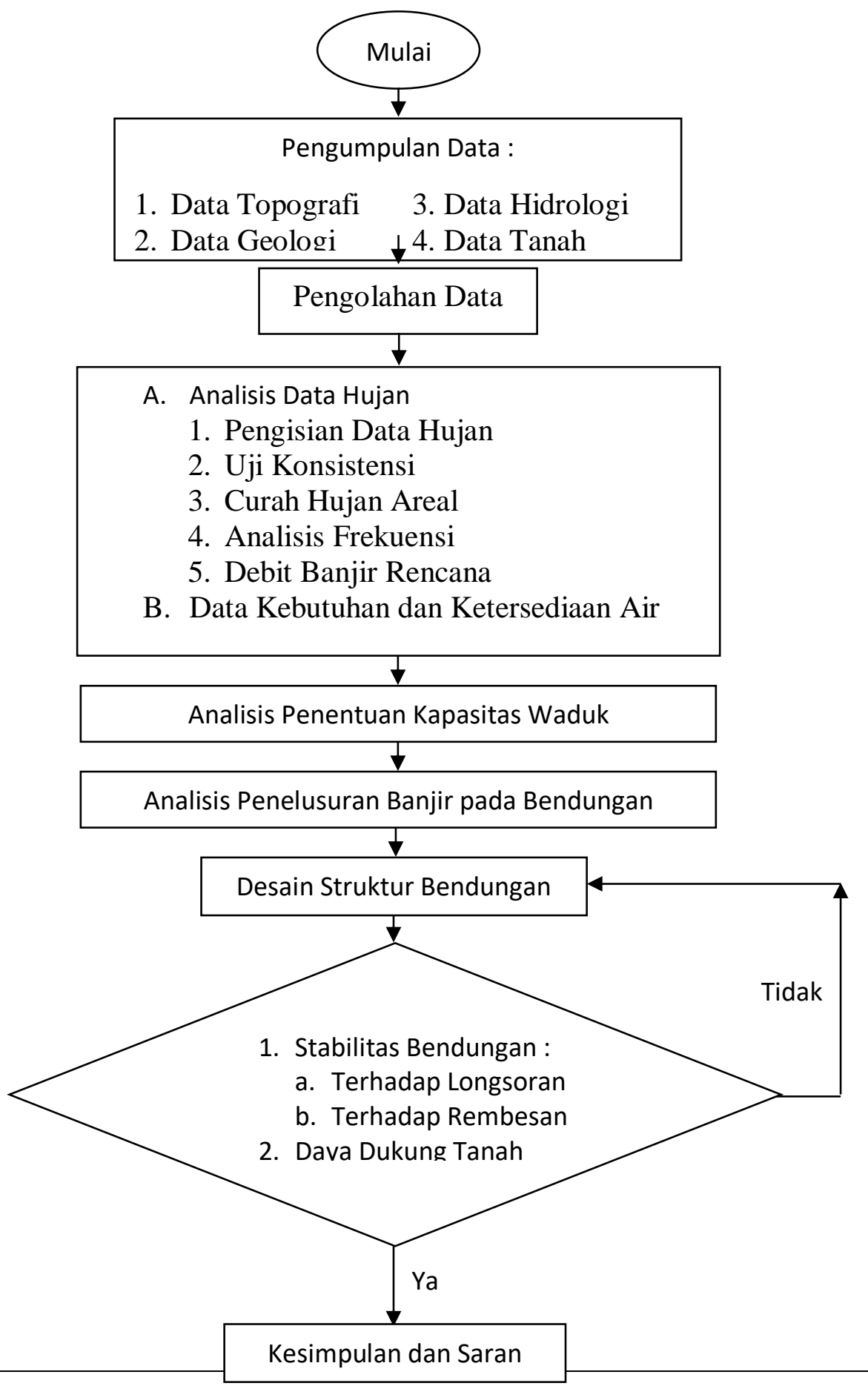




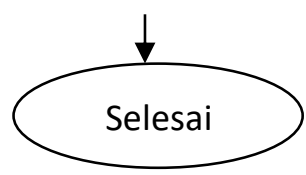

\section{Hasil Pembahasan}

Gambar 2 Bagan Alir Perencanaan Bendungan Bandungharjo

Hujan merupakan komponen yang penting dalam proses hidrologi, karena jumlah kedalaman hujan (rain fall depth) ini yang dialihragamkan menjadi aliran sungai, baik melalui limpasan permukaan, aliran antara, maupun sebagai aliran antara. Hujan juga merupakan potensi ketersediaan air, yang dapat dimanfaatkan oleh tanaman (hujan efektif).

\section{Pengisian Data Hujan}

Data yang didapatkan selama 15 tahun dan dari 4 stasiun pengamatan hujan yang berada di sekitar Sub DAS Kali Glugu, tidak semuanya terisi disetiap harinya. Kekosongan data yang di sebabkan kerusakan alat ini, perlu diisi dengan Reciprocal Method (Sri Harto, 1993), yang memanfaatkan jarak antar stasiun sebagai koreksi. Metode ini menggunakan paling tidak 3 stasiun hujan. Adapun persamaannya adalah sebagai berikut :

$\operatorname{Px}=\left[\frac{P_{A} /\left(d_{X A}\right)^{2}+P_{B} /\left(d_{X B}\right)^{2}+\ldots \ldots+P_{c} /\left(d_{x c}\right)^{2}}{1 /\left(d_{X A}\right)^{2}+1 /\left(d_{X B}\right)^{2}+\ldots . .+1 /\left(d_{x c}\right)^{2}}\right]$

Analisis dalam pengisian data hujan pada penelitian ini di setiap stasiun hujan menggunakan 3 stasiun pengamatan hujan lainnya sebagai back up, yang dianggap sebagai 3 stasiun hujan terdekat, yang diantaranya adalah :

Stasiun Hujan Geyer

Stasiun Hujan Asemrudung

Stasiun Hujan Sanggeh

Stasiun Hujan Semen
: a. Stasiun Hujan Asemrudung

b. Stasiun Hujan Sanggeh

c. Stasiun Hujan Semen

: a. Stasiun Hujan Geyer

b. Stasiun Hujan Sanggeh

c. Stasiun Hujan Semen

: a. Stasiun Hujan Geyer

b. Stasiun Hujan Asemrudung

c. Stasiun Hujan Semen

: a. Stasiun Hujan Geyer

b. Stasiun Hujan Asemrudung

c. Stasiun Hujan Sanggeh

\section{Uji Konsistensi}

Setelah data hujan terisi secara keseluruhan, maka data yang ada perlu diuji konsistensi atau kepanggahannya. Pengujian ini dilakukan untuk meminimalisir penyimpangan data hujan yang ada. Pengujian ini dilakukan dengan metode RAPS (Rescaled Adjusted Partial Sums) yang menggunakan persamaan sebagai berikut :

$$
\mathrm{N}=\sum_{\mathrm{i}=1}^{\mathrm{n}}\left(\mathrm{Y}_{\mathrm{i}}-\overline{\mathrm{Y}}\right)^{2}
$$

Tabel V.1. Perhitungan Uji Konsistensi Data Hujan Stasiun Pengamatan Geyer

\begin{tabular}{|c|c|c|c|c|c|}
\hline Tahun & $\begin{array}{c}\text { Hujan } \\
(\text { Yi })\end{array}$ & Yi $-\tilde{Y}$ & $(Y i-\tilde{Y})^{2}$ & Ski* $=$ Kom $(Y i-\tilde{Y})$ & Ski** = Ski*/Dy \\
\hline
\end{tabular}




\begin{tabular}{cccccc}
\hline 1998 & 3620 & 1468,933 & 2157765,138 & 1468,933 & 2,381 \\
\hline 1999 & 3244 & 1092,933 & 1194503,271 & 2561,867 & 4,153 \\
\hline 2000 & 2150 & $-1,067$ & 1,138 & 2560,800 & 4,151 \\
\hline 2001 & 1776 & $-375,067$ & 140675,004 & 2185,733 & 3,543 \\
\hline 2002 & 1357 & $-794,067$ & 630541,871 & 1391,667 & 2,256 \\
\hline 2003 & 1776 & $-375,067$ & 140675,004 & 1016,600 & 1,648 \\
\hline 2004 & 1710 & $-441,067$ & 194539,804 & 575,533 & 0,933 \\
\hline 2005 & 1890 & $-261,067$ & 68155,804 & 314,467 & 0,510 \\
\hline 2006 & 2084 & $-67,067$ & 4497,938 & 247,400 & 0,401 \\
\hline 2007 & 2290 & 138,933 & 19302,471 & 386,333 & 0,626 \\
\hline 2008 & 1769 & $-382,067$ & 145974,938 & 4,267 & 0,007 \\
\hline 2009 & 1540 & $-611,067$ & 373402,471 & $-606,800$ & $-0,984$ \\
\hline 2010 & 2864 & 712,933 & 508273,938 & 106,133 & 0,172 \\
\hline 2011 & 2348 & 196,933 & 38782,738 & 303,067 & 0,491 \\
\hline 2012 & 1848 & $-303,067$ & 91849,404 & 0,000 & 0,000 \\
\hline$\tilde{Y}=\Sigma Y \mathrm{Yi} / \mathrm{n}$ & 2151,067 & 0,000 & 5708940,933 & & 4,153 \\
\hline Dy $=\sqrt{\Sigma}(\mathrm{Yi}-\tilde{Y})^{2} / \mathrm{n}=$ & 616,925 & & & \\
\hline
\end{tabular}

\section{Kesimpulan}

Berdasarkan analisis dan pembahasan di awal, maka dapat disimpulkan bahwa :

1. Lokasi as bendungan terletak di Selatan Dusun Klumpit yaitu pada $110^{\circ} 15^{\prime}$ BT- $111^{\circ} 25^{\prime}$ BT dan $7^{\circ}$ LS-7ํㅜㄴ LS Desa Bandungharjo Kecamatan Toroh.

2. Bendungan Bandungharjo dibangun dengan Bendungan Tipe Urugan Zonal dengan Inti Kedap Air Tegak dengan tinggi bendungan $38 \mathrm{~m}$.

3. Inti Kedap Air menggunakan material lempung, sisi hulu menggunakan material tanah urugan dengan di atasnya menggunakan pasir dan rip-rap (batuan) sebagai pelindung lereng pada kondisi penurunan mendadak (rapid drawdown) dan hilir bendungan menggunakan material tanah urug.

4. Pada kaki hilir bendungan dibangun filter sebagai drainase rembesan pada tubuh bendungan dengan menggunakan material batuan dan pasir.

5. Volume total kapasitas Bendungan Bandungharjo sebesar 17735790,9254 $\mathrm{m}^{3}$.

6. Kontrol kestabilan terhadap longsoran dihitung dengan Metode Irisan Bidang Luncur Bundar pada kondisi bendungan selesai dibangun, kondisi muka air banjir dan kondisi penurunan mendadak (rapid drawdown) baik dengan adanya beban gempa $(\mathrm{e}=0,25 \mathrm{~g})$ dan tanpa adanya beban gempa dan didapatkan hasil aman

7. Kontrol kestabilan terhadap filtrasi (rembesan) menggunakan Metode A.Casagrande pada perhitungan garis depresinya dan Metode Dupuit pada perhitungan jaringan trayektorinya, sehingga diperoleh Kapasitas Rembesan sebesar Qf $=98,152 \mathrm{~m}^{3} / \mathrm{hari}=0,00114 \mathrm{~m}^{3} /$ detik.

8. Daya dukung tanah pada Perencanaan Bendungan Bandungharjo ini menggunakan Metode Terzaghi pada kondisi keruntuhan geser lokal (Local Shear Failure) diperoleh hasil SF $=3,425$ $(\mathrm{SF}>3)$. 
Daftar Pustaka

Hardiyatmo, HC. 1994. Mekanika Tanah 1. PT. Gramedia Pustaka Utama. Jakarta.

Hardiyatmo, HC. 2002. Mekanika Tanah 2. Gajah Mada University Press. Jakarta.

Harto, Sri. 1993. Analisis Hidrologi. Erlangga. Jakarta.

Pratama, A. Ardhani dkk. 2009. Perencanaan Bendungan Gonggang Kabupaten Magetan Jawa Timur. Universitas Diponegoro Semarang.

Triatmodjo, Bambang. 1999. Teknik Pantai. PT. Beta Offset. Yogyakarta.

Triatmodjo, Bambang. 2008. Hirologi Terapan. Betta Offset. Yogyakarta.

Soedibyo. 1993. Teknik Bendungan. PT. Pradnya Paramita. Jakarta.

Soemarto, CD. 1995. Hidrologi Teknik Edisi Ke-2. Erlangga. Jakarta.

Sosrodarsono, Suyono. 1993. Bendungan Type Urugan. PT. Pradnya Paramita. Jakarta.

Sudjarwadi. 1987. Teknik Sumber Daya Air. Keluarga Mahasiswa Teknik Sipil Universitas Gajah Mada. Yogyakarta.

Susilo, Budi. 1994. Mekanika Tanah Edisi Ke-4. PT. Erlangga. Jakarta.

Wulandari, Indah. 2009. Tinjauan Kembali Bendungan Kedung Ombo dalam Hal Kelayakan Elevasi Mercu Bendungan. Universitas Muhammadiyah Surakarta. 